\title{
Kepatuhan Syariah (Sharia Compliance) dalam Industri Keuangan Syariah
}

\author{
Luqman Nurhisam \\ Universitas Islam Negeri Sunan Kalijaga Yogyakarta \\ Jln. Marsda Adisucipto Yogyakarta \\ luckyman46@gmail.com
}

\begin{abstract}
The fact that it is obliged to Sharia Supervision Board (DPS) in every Sharia Bank Financial Industry (IKBS) and non-bank financial industry (IKNBS) to abide by sharia conditions has made sharia supervision inseparable from sharia compliance. Such thing can be seen from several regulations issued by DPS-MUI which become a reference for IKBS and IKNBS in running their activities in the sector of sharia finance. This research focuses on the regulations issued by DSN-MUI and their implementation regarding IKBS IKNBS, as well as DPS as the one having the authority to supervise every sharia-based finance industry. This was a normative research, which searches for data in the form of books and other written data which have correlation with the research object by using descriptive-analytic approach. The findings show that DPS as the one having the authority to supervise sharia compliance, has responsibility as stated by a strict legal system. The existence of DPS really determines the establishment of sharia compliance, which becomes the main unsure in the existence and continuity of syariah financial industry.
\end{abstract}

Keywords: Sharia compliance, sharia supervision board, bank finance industry

\begin{abstract}
Abstrak
Diwajibkannya keberadaan Dewan Pengawas Syariah (DPS) pada setiap Industri Keuangan Bank Syariah (IKBS) maupun Industri Keuangan Non-Bank Syariah (IKNBS) untuk mematuhi ketentuanketentuan syariah telah menjadikan pengawasan syariah sebagai bagian yang tidak terpisahkan dengan kepatuhan syariah (sharia compliance). Hal tersebut bisa dilihat dari beberapa regulasi yang dikeluarkan oleh DPS-MUI yang menjadi acuan bagi industri IKBS dan IKNBS dalam menjalankan aktifitasnya di bidang keuangan syariah. Penelitian ini fokus kepada regulasi yang dikeluarkan oleh DSN-MUI serta implementasinya terhadap lembaga IKBS dan IKNBS, serta DPS sebagai pihak yang berwenang mengawasi setiap industri keuangan berbasis syariah. Jenis penelitian yang digunakan adalah penelitian normatif, yaitu mencari data-data berupa buku-buku atau data-data tertulis lainnya yang memiliki korelasi dengan objek penelitian dengan menggunakan pendekatan deskriptif-analitis. Hasil penelitian menyimpulkan bahwa DPS sebagai pemegang otoritas pengawasan terhadap kepatuhan syariah (sharia compliance), memiliki tanggungjawab yang diatur melalui ketentuan hukum yang tegas. Kedudukan DPS sangat menentukan terciptanya kepatuhan syariah (sharia compliance) yang merupakan unsur utama dalam keberadaan dan kelangsungan usaha bagi industri keuangan syariah.
\end{abstract}

Kata kunci: Kepatuhan syariah, dewan pengawas syariah, industri keuangan bank. 


\section{Pendahuluan}

Secara konseptual, industri keuangan syariah memang sesuai dengan tuntutan perkembangan zaman serta sudah menjadi kewajiban sejarahnya untuk lahir dan tumbuh menjadi sistem keuangan yang alternatif-solutif. Untuk merealisasikan hal ini bukanlah hal yang mudah, banyak tantangan dan rintangan yang harus dihadapi oleh industri keuangan syariah ke depan nanti. Industri keuangan syariah baik bank maupun non-bank yang saat ini masih dalam tahap awal evolusinya. Walaupun tingkat pertumbuhannya cukup cepat, sejauh ini baru menempati ceruk kecil (small niche) di sektor finansial negeri-negeri muslim, apalagi di sektor keuangan internasional. Meskipun terdapat sejumlah kesulitan, gerakan Islamisasi perbankan berjalan dengan baik. Kemajuan yang dicapai selama seperempat abad terakhir ini menunjukkan hasil yang menggembirakan. ${ }^{1}$

Meskipun institusi keuangan itu selalu berevolusi, kebangkitan keuangan Islam tidak dapat dikatakan sebagai semata-mata proses evolusi dari industri keuangan yang ada. Harus dipahami bahwa pandangan hidup muslim (worldview) yang melihat Islam sebagai sebuah perangkat aturan dari perilaku untuk seluruh area kehidupan termasuk aspek ekonomi, merupakan sebuah kekuatan pendorong (driving force) atas kelahiran industri keuangan Islam. Sebagai industri keuangan yang berbasis pada agama, industri keuangan yang menjalankan aktivitas berbasis Islam karenanya secara ketat didikte oleh ajaran agama, yakni al-Qur'an dan Sunnah Rasulullah SAW. Sistem keuangan Islam secara substansial berbeda dari industri keuangan yang masih menggunakan sistem konvensional. Ada kaitan yang erat antara aspek konseptual dan praktis dari aktivitas bisnis keuangan dan prinsip-prinsip Islam atau syariah. Dengan kata lain, salah satu aspek mendasar yang membedakan industri keuangan syariah dan konvensional adalah perihal kepatuhan pada prinsip syariah (sharia compliance). ${ }^{2}$

Salah satu aspek hukum dalam industri keuangan syariah adalah regulasi tentang kepatuhan syariah (sharia compliance). Kepatuhan syariah adalah bagian

${ }^{1}$ Aziz Budi Setiawan, "Perbankan Syariah: Challenges dan Opportunity Untuk Pengembangan di Indonesia”, Jurnal Kordinat, Vol. VIII 1, April 2006, hlm. 14.

${ }^{2}$ Abdullah M. Noman, "Imperatives of Financial Innovations For Islamic Banks", International Journal of Islamic Financial Services, Vol. 3, (2003), hlm. 5. 
penting bagi industri keuangan syariah dalam segi pengelolaan (manajemen) maupun operasionalnya. Hal itu didukung dengan mengharuskan keberadaaan Dewan Pengawas Syariah (DPS) bagi setiap institusi keuangan berbasis syariah. Dewan Pengawas Syariah (DPS) bertugas mengawasi penerapan kontrak atau akad apakah penerapannya sudah sesuai dengan prinsip-prinsip yang ada di dalam syariah.

Perangkat regulasi yang didesain secara spesifik untuk mengatur kepatuhan syariah tidak lagi dapat dihindari penyiapannya. Tuntutan untuk meningkatkan kerangka regulasi bagi kepatuhan syariah merupakan sebuah tantangan yuridis yang dihadapi oleh setiap negara yang berkeinginan untuk mengembangan bisnis keuangan berbasis Islam (syariah). Negara-negara tersebut ditantang untuk mereformulasi kerangka hukum mereka agar mampu secara sepenuhnya mengakomodasi kekhasan dari keuangan Islam (syariah). ${ }^{3}$

Selama kepatuhan terhadap prinsip-prinsip syariah merupakan keharusan bagi industri keuangan syariah, maka pengawasan (supervisory) syariah ada di Indonesia. Sehingga dapat dikatakan bahwa pengawasan syariah oleh Dewan Pengawas Syariah (DPS) merupakan bagian tak terpisahkan dari kepatuhan syariah. Dalam konteks ini, regulasi tentang pengawasan syariah, tentu saja mencakup di dalamnya keberadaan dewan syariah (sharia board), yang mana adalah bagian penting dari kerangka aturan-aturan regulasi sebagai kepatuhan syariah (sharia compliance). ${ }^{4}$ Berdasarkan pemikiran tersebut di atas, maka kajian terkait dengan instumen pengawasan syariah pada lembaga keuangan syariah, penting untuk dilakukan.

\section{Rumusan Masalah}

Permasalahan dalam penelitian ini yaitu bagaimana konsep dan implementasi aturan-aturan dalam bentuk fatwa DSN-MUI oleh Dewan Pengawas syariah (DPS) sebagai wujud kepatuhan syariah (sharia compliance) terhadap Industri Keuangan Syariah Baik bank (IKBS) maupun non-bank (IKNBS)? 


\section{Tujuan Penelitian}

Tujuan yang hendak dicapai dalam penelitian ini adalah untuk menjelaskan konsep dan penerapan aturan-aturan dalam bentuk fatwa DSN-MUI oleh Dewan Pengawas Syariah (DPS) sebagai wujud kepatuhan syariah (sharia compliance) terhadap Industri Keuangan Syariah Baik bank (IKBS) maupun non-bank (IKNBS).

\section{Metode Penelitian}

Penelitian ini merupakan penelitian normatif. Pendekatan penelitian ini menggunakan pendekatan perundang-undangan (statute approach), karena permasalahan dalam penelitian ini didekati dengan norma-norma hokum positif dan hukum Islam. Regulasi sebagai bentuk kepatuhan syariah terhadap industri keuangan syariah bank (IKBS) maupun non-bank (IKNBS).

Pengumpulan data melalui penelitian kepustakaan (library research) yaitu penelitian yang dilakukan hanya berdasarkan atas karya tertulis, termasuk hasil penelitian baik yang telah maupun yang belum dipublikasikan. Penelitian dokumen adalah penelitian yang dilakukan dengan melihat sejumlah data berupa: data arsip, data resmi pada institusi-institusi pemerintah, data yang dipublikasikan (Putusan Pengadilan, Jurisprudence, dan sebagainya). Sedangkan untuk mendapatkan data tentang objek dari penelitian ini adalah dengan menggunakan dokumen berupa peraturan BI (PBI/SEBI), Peraturan OJK (POJK), serta fatwa DSNMUI, serta ketentuan-ketentuan berupa guidelines terhadap industri keuangan syariah bank (IKBS) maupun non-bank (IKNBS). Sedangkan data pendukung akan di dapatkan melalui literatur-literatur yang berkaitan dengan pokok pembahasan yang ada. Teknik analisis data yaitu deskriptif-analitis. Penelitian deskriptif merupakan penelitian yang dimaksudkan untuk mengumpulkan informasi mengenai status suatu gejala yang ada, yaitu gejala menurut apa adanya saat penelitian dilakukan. ${ }^{5}$ Sedangkan analisis adalah sebuah usaha untuk mencari dan menata secara sistematis data-data penelitian untuk kemudian dilakukan

${ }^{5}$ Suharsimi Arikunto, Manajemen Penelitian, cet. Ke-5, Rineka Cipta, Jakarta, 2000, hlm. 39. 
penelaahan guna mencari makna. ${ }^{6}$ Gambaran mengenai konsep dari regulasi yang ada terhadap industri keuangan syariah bank (IKBS) maupun non-bank (IKNBS) diuraikan seperti apa adanya. Setelah data terkumpul dilanjutkan dengan analisa agar dapat menjawab pokok permasalahan.

\section{Hasil Penelitian dan Pembahasan}

Hukum Islam bersumber pada al-Qur'an dan Sunnah, prinsip-prinsip syariah merupakan segala ketentuan yang berlandaskan pada sumber hukum tersebut. Untuk menerapkan prinsip-prinsip yang ada di dalam syariah, dilakukan aturan teknis sama halnya seperti dalam membuat peraturan perundangundangan pada umumnya. Aturan tersebut berasal dari prinsip-prinsip syariah dibuat oleh pemberi atau pembuat hukum yang secara khusus di mana sistem hukum keuangan berasal. ${ }^{7}$

Prinsip syariah merupakan acuan utama bagi Dewan Syariah Nasional (DSN) dalam menyusun fatwa terkait aktivitas keuangan berbasis syariah yang ditujukan bagi industri keuangan syariah. Tidak hanya itu, adanya prinsip syariah digunakan untuk mengakomodasi Dewan Pengawas Syariah dalam pengawasan kepada industri keuangan syariah baik bank (IKBS) maupun non-bank (IKNB). Karena setiap industri keuangan syariah baik bank maupun non-bank diwajibkan memiliki dewan pengawas, yang secara otomatis baik industri keuangan syariah bank maupun non-bank terikat dengan adanya aturan-aturan syariah sebagaimana yang telah ditetapkan, hal ini dinamakan dengan kepatuhan syariah (syariah compliance).

\section{Regulasi dan Fatwa Terkait dengan Lembaga Keuangan Syariah di Indonesia}

\section{Perbankan Syariah}

Regulasi kepatuhan syariah diawali dengan aturan terhadap perbankan yang menjalankan aktifitasnya di bidang syariah. Sesuai dengan amandemen UU

${ }^{6}$ Noeng Moehajir, Metode Penelitian Kualitatif, ed. III, cet.Ke-7, Rake Sarasin, Yogyakarta, 1998, hlm. 104.

${ }^{7}$ Haniah Ilhami, "Pertanggungjawaban Dewan Pengawas Syariah Sebagai Otoritas Pengawas Kepatuhan Syariah Bagi Bank Syariah”, Mimbar Hukum, Vol. 21, No. 3, Oktober 2009, hlm. 479. 
No. 7 Tahun 1992 yang menjadi UU No. 10 Tahun 1998 tentang Perbankan sebagai awal bagi beroperasinya perbankan syariah di Indonesia. Masih lemahnya peraturan yang ada di dalam UU tersebut, karena singkatnya aturan terkait perbankan yang menjalankan aktifitasnya di syariah, maka dikeluarkannya aturan dari Bank Indonesia dalam bentuk Peraturan Bank Indonesia (PBI) dan Surat Edaran Bank Indonesia (SEBI). Diterbitkannya Peraturan Bank Indonesia (PBI) No. 7/35/PBI/2005 tentang Perubahan Atas Peraturan Bank Indonesia No. 6/24/PBI/2004 tentang Bank Umum yang Melaksanakan Kegiatan Usaha Berdasarkan Prinsip Syariah, serta PBI No. 8/3/PBI/2006 tentang Perubahan Kegiatan Usaha Bank Umum Konvensional Menjadi Bank Umum yang Melaksanakan Kegiatan Usaha Berdasarkan Prinsip Syariah dan Pembukaan Kantor Bank yang Melaksanakan Kegiatan Usaha Berdasarkan Prinsip Syariah oleh Bank Umum Konvensional. Sehubungan dengan regulasi sebelumnya, maka diterbitkannya UU No. 21 Tahun 2008 tentang Perbankan Syariah, yang lebih tegas dan terintegrasi dalam mengatur perbankan syariah yang ada di Indonesia. Selanjutnya beraneka ragam regulasi terkait pengembangan aturan seiring dengan kemajuan industri perbankan syariah, berikut aturan dari Bank Indonesia baik dari PBI maupun dalam bentuk SEBI: ${ }^{\circ}$

1. Surat Edaran Bank Indonesia No. 11/9/DPbS tanggal 7 April 2009 perihal Bank Umum Syariah;

2. Surat Edaran Bank Indonesia Nomor 11/28/DPbS tanggal 5 Oktober 2009 perihal Unit Usaha Syariah;

3. Peraturan Bank Indonesia Nomor 11/3/PBI/2009 tentang Bank Umum Syariah;

4. Peraturan Bank Indonesia Nomor 11/10/PBI/2009 tentang Unit Usaha Syariah;

5. Surat Edaran Bank Indonesia Nomor $15 / 50 / \mathrm{DPbS}$ tentang Perubahan Atas Surat Edaran Bank Indonesia No. 11/9/DPbS tanggal 7 April 2009 perihal Bank Umum Syariah;

6. Surat Edaran Bank Indonesia Nomor $15 / 51 / \mathrm{DPbS}$ tentang Perubahan Atas Surat Edaran Bank Indonesia Nomor 11/28/DPbS tanggal 5 Oktober 2009 perihal Unit Usaha Syariah;

7. Peraturan Bank Indonesia Nomor 15/13/PBI/2013 tentang Perubahan Atas Peraturan Bank Indonesia Nomor 11/3/PBI/2009 tentang Bank Umum Syariah;

8. Peraturan Bank Indonesia Nomor 15/14/PBI/2013 tentang Perubahan Atas Peraturan Bank Indonesia Nomor 11/10/PBI/2009 tentang Unit Usaha Syariah;

8Peraturan Bank Indonesia, http://www.bi.go.id/id/peraturan/perbankan/Default.aspx, diakses tanggal 20 Desember 2015. 
9. Surat Edaran Bank Indonesia Nomor 15/44/DPbS tentang Fasilitas Pendanaan Jangka Pendek Syariah bagi Bank Umum Syariah;

10. Surat Edaran Bank Indonesia Nomor 15/26/DPbS tentang Pelaksanaan Pedoman Akuntansi Perbankan Syariah Indonesia;

11. Surat Edaran Bank Indonesia Nomor 15/22/DPbS tentang Pedoman Pelaksanaan Tugas dan Tanggung Jawab Dewan Pengawas Syariah Bank Pembiayaan Rakyat Syariah;

12. Surat Edaran Bank Indonesia Nomor 15/8/DPbS tentang Pembukaan Jaringan Kantor Bank Umum Syariah dan Unit Usaha Syariah Berdasarkan Modal Inti;

13. Peraturan Bank Indonesia Nomor 14/20/PBI/2012 tentang Perubahan Peraturan Bank Indonesia Nomor 11/24/PBI/2009 tentang Fasilitas Pendanaan Jangka Pendek Syariah Bagi Bank Umum Syariah; dan

14. Surat Edaran Bank Indonesia Nomor 14/33/DPbS tentang Penerapan Kebijakan Produk Pembiayaan Kepemilikan Rumah dan Pembiayaan Kendaraan Bermotor bagi Bank Umum Syariah dan Unit Usaha Syariah.

Regulasi di atas tidak menutup aturan-aturan sebelumnya, karena aturanaturan sebelum undang-undang ini lahir masih tetap berlaku sepanjang hal-hal yang tidak diatur dalam undang-undang ini.selanjutnya, aspek lain yang penting untuk menunjang regulasi perbankan syariah adalah dikeluarkannya aturan-aturan berdasarkan prinsip syariah dalam bentuk fatwa-fatwa oleh DSN-MUI, sebagai berikut: 9

1. Fatwa No. 16/DSN-MUI/IX/2000 tentang Diskon dalam Murabahah

2. Fatwa No. 17/DSN-MUI/IX/2000 tentang Sanksi atas Nasabah Mampu yang Menunda-nunda Pembayaran

3. Fatwa No. 18/DSN-MUI/IX/2000 tentang Pencadangan Penghapusan Aktiva Produktif Dalam LKS

4. Fatwa No. 19/DSN-MUI/IX/2000 tentang Al-Qardh

5. Fatwa No. 20/DSN-MUI/IX/2000 tentang Pedoman Pelaksanaan Investasi untuk Reksa Dana Syariah

6. Fatwa No. 21/DSN-MUI/X/2001 tentangPedoman Umum Asuransi Syari'ah

7. Fatwa No. 22/DSN-MUI/III/2002 tentangJual Beli Istishna' Paralel

8. Fatwa No. 23/DSN-MUI/III/2002 tentang Potongan Pelunasan Dalam Murabahah

9. Fatwa No. 24/DSN-MUI/III/2002 tentangSafe Deposit Box

10. Fatwa No. 25/DSN-MUI/III/2002tentang Rahn

11. Fatwa No. 26/DSN-MUI/III/2002tentang Rahn Emas

12. Fatwa No. 27/DSN-MUI/III/2002tentang Al-Ijarah al-Muntahiya bi al-Tamlik

13. 28/DSN-MUI/III/2002tentang Jual Beli Mata Uang (al-Sharf)

14. Fatwa No. 29/DSN-MUI/VI/2002tentang Pembiayaan Pengurusan Haji LKS

${ }^{9}$ Fatwa DSN-MUI, http://mui.or.id/produk-mui/fatwa-mui/fatwa-dsn-mui, diakses tanggal 20 Desember 2015. 
15. Fatwa No. 30/DSN-MUI/VI/2002tentang Pembiayaan Rekening Koran Syari'ah

16. Fatwa No. 31/DSN-MUI/VI/2002tentang Pengalihan Utang

17. Fatwa No. 34/DSN-MUI/IX/2002tentang L/C Impor Syari'ah

18. Fatwa No. 35/DSN-MUI/IX/2002tentang L/C Ekspor Syari'ah

19. Fatwa No. 36/DSN-MUI/X/2002 tentang Sertifikat Wadi'ah Bank Indonesia

20. Fatwa No. 37/DSN-MUI/X/2002 tentang Pasar Uang Antarbank Berdasarkan Prinsip Syari'ah

21. Fatwa No. 38/DSN-MUI/X/2002 tentang Sertifikat Investasi Mudharabah Antarbank (Sertifikat IMA)

22. Fatwa No. 39/DSN-MUI/X/2002 tentang Asuransi Haji

23. Fatwa No. 42/DSN-MUI/V/2004 tentang Syari'ah Charge Card

24. Fatwa No. 43/DSN-MUI/VIII/2004 tentang Ganti Rugi (Ta'widh)

25. Fatwa No. 44/DSN-MUI/VIII/2004 tentang Pembiayaan Multijasa

26. Fatwa No. 45/DSN-MUI/II/2005 tentang Line Facility

27. Fatwa No. 46/DSN-MUI/II/2005 tentang Potongan Tagihan Murabahah

28. Fatwa No. 47/DSN-MUI/II/2005 tentang Penyelesaian Piutang Murabahah bagi Nasabah Tak Mampu Bayar

29. Fatwa No. 48/DSN-MUI/II/2005 tentang Penjadwalan Kembali Tagihan Murabahah

30. Fatwa No. 49/DSN-MUI/II/2005 tentang Konversi Akad Murabahah

31. Fatwa No. 50/DSN-MUI/III/2006 tentang Akad Mudharabah Musytarakah

32. Fatwa No. 51/DSN-MUI/III/2006 tentang Akad Mudharabah Musytarakah pada Asuransi Syari'ah

33. Fatwa No. 52/DSN-MUI/III/2006 tentang Akad Wakalah Bil Ujrah pada Asuransi dan Reasuransi Syari'ah

34. Fatwa No. 53/DSN-MUI/III/2006 tentang Akad Tabarru' pada Asuransi dan Reasuransi Syari'ah

35. Fatwa No. 54/DSN-MUI/X/2006 tentang Syari'ah Card

36. Fatwa No. 55/DSN-MUI/V/2007 tentang Pembiayaan Rekening Koran Syari'ah Musyarakah

37. Fatwa No. 56/DSN-MUI/V/2007 tentang Ketentuan Review Ujrah Pada Lembaga Keuangan Syari'ah

38. Fatwa No. 57/DSN-MUI/V/2007 tentang Letter of Credit (LC) dengan Akad Kafalah bil Ujrah

39. Fatwa No. 58/DSN-MUI/V / 2007 tentang Hawalah bil Ujrah;

40. Fatwa No. 59/DSN-MUI/V/2007 tentang Obligasi Syari'ah Mudharabah Konversi;

41. Fatwa No. 60/DSN-MUI/V / 2007 tentang Penyelesaian Piutang Dalam Ekspor;

42. Fatwa No. 61/DSN-MUI/V/2007 tentang Penyelesaian Utang Dalam Impor.

\section{Regulasi dan Fatwa Terkait Pasar Modal Syariah}

Regulasi industri keuangan syariah non-bank diawali dengan adanya aturan dalam kegiatan usaha perasuransian, terbitnya Peraturan Menteri Keuangan Nomor 
18/PMK.010/2010 tentang Prinsip Dasar Penyelenggaraan Usaha Asuransi dan Usaha Reasuransi dengan Prinsip Syariah. Selanjutnya Peraturan Menteri Keuangan Nomor 11/PMK.010/2011 tentang Kesehatan Keuangan Usaha Asuransi dan Usaha Reasuransi dengan Prinsip Syariah, adanya peraturan menteri keuangan tersebut dibuat untuk menerapkan prinsip kehati-hatian serta menjaga keseimbangan antara kekayaan dan kewajiban dalam penyelenggaraan usaha asuransi dan usaha reasuransi dengan prinsip syariah.Hal ini sebagaimana telah diatur dalam Peraturan Pemerintah (PP) Nomor 39 Tahun 2008 tentang Perubahan Kedua atas Peraturan Pemerintah Nomor 73 Tahun 1992 tentang Penyelenggaraan Usaha Perasuransian sebagaimana telah beberapa kali diubah terakhir dengan Peraturan Pemerintah Nomor 81 Tahun 2008. Berikutnya, Peraturan Ketua Bapepam-LK Nomor: PER06/BL/2011 tentang Bentuk dan Susunan Laporan serta Pengumuman Laporan Usaha Asuransi dan Usaha Reasuransi dengan Prinsip Syariah. Tidak hanya itu, aturan mengenai asuransi syariah diperkuat dengan adanya Peraturan Ketua Bapepam-LK Nomor: PER-08/BL/2011 tentang Bentuk dan Tata Cara Penyampaian Laporan Hasil Pengawasan Dewan Pengawas Syariah pada Perusahaan Asuransi atau Perusahaan Reasuransi yang Menyelenggarakan Seluruh atau Sebagian Usahanya dengan Prinsip Syariah. ${ }^{10}$

Sebagai dasar peletakan bagi operasional pasar modal syariah, diawali dengan adanya Peraturan Ketua Bapepam-LK Nomor: PER-06/BL/2012 tentang Perubahan atas Peraturan Ketua Badan Pengawas Pasar Modal dan Lembaga Keuangan Nomor PER-03/BL/2007 tentang Kegiatan Perusahaan Pembiayaan Berdasarkan Prinsip Syariah. Selanjutnya oleh OJK ada beberapa aturan terkait pasar modal syariah, yaitu: ${ }^{11}$

1. POJK Nomor 15/POJK.04/2015 tentang Penerapan Prinsip Syariah di Pasar Modal;

2. POJK Nomor 16/POJK.04/2015tentang Ahli Syariah Pasar Modal;

3. POJK Nomor 17/POJK.04/2015 tentang Penerbitan dan Persyaratan Efek Syariah Berupa Saham oleh Emiten Syariah atau Perusahaan Publik Syariah;

4. POJK Nomor 18/POJK.04/2015 tentang Penerbitan dan Persyaratan Sukuk, POJK Nomor 19/POJK.04/ 2015 tentang Penerbitan dan Persyaratan Reksa Dana Syariah;

\footnotetext{
${ }^{10}$ Peraturan OJK, http://www.ojk.go.id/id/regulasi/otoritas-jasa-keuangan/peraturan-ojk/Default.aspx, diakses tanggal 20 Desember 2015.

${ }^{11}$ Ibid.
} 
5. POJK Nomor 20/POJK.04/2015 tentang Penerbitan dan Persyaratan Efek Beragun Aset Syariah;

6. POJK Nomor 53/POJK.04/2015 POJK tentang akad yang Digunakan dalam Penerbitan Efek Syariah di Pasar Modal; dan

7. Peraturan Nomor II.K.1: Kriteria dan Penerbitan Daftar Efek Syariah.

Aturan mengenai pasar modal syariah diperkuat dengan fatwa yang dikeluarkan oleh DSN-MUI, yaitu; ${ }^{12}$

1. Fatwa No. 20/DSN-MUI/IX/2001 tentang Pedoman Pelaksanaan Investasi Untuk Reksadana Syariah

2. Fatwa No. 32/DSN-MUI/IX/2002 tentang Obligasi Syariah

3. Fatwa No. 33/DSN-MUI/IX/2002 tentang Obligasi Syariah Mudharabah.

4. Fatwa No. 37/DSN-MUI/X/2002tentang Pasar Uang Antarbank Berdasarkan Prinsip Syari'ah.

5. Fatwa No. 40/DSN-MUI/X/2003 tentang Pasar Modal dan Pedoman Umum Penerapan Prinsip Syariah di Bidang Pasar Modal

6. Fatwa No. 41/DSN-MUI/III/2004 tentang Obligasi Syariah Ijarah

7. Fatwa No. 59/DSN-MUI/V/2007 tentang Obligasi Syariah Mudharabah Konversi

8. Fatwa No. 65/DSN-MUI/III/2008 tentang Hak Memesan Efek Terlebih Dahulu (HMETD) Syariah

9. Fatwa No. 66/DSN-MUI/III/2008 tentang Waran Syariah

10. Fatwa No. 69/DSN-MUI/VI/2008 tentang Surat Berharga Syariah Negara (SBSN)

11. Fatwa No. 70/DSN-MUI/VI/2008 tentang Metode Penerbitan SBSN

12. Fatwa No. 71/DSN-MUI/VI/2008 tentang Sale and Lease Back

13. Fatwa No. 72/DSN-MUI/VI/2008 tentang SBSN Ijarah Sale and Lease Back

14. Fatwa No. 76/DSN-MUI/VI/2010 tentang SBSN Ijarah Asset To Be Leased

15. Fatwa No. 80/DSN-MUI/III/2011 tentang Penerapan Prinsip Syariah dalam Mekanisme Perdagangan Efek Bersifat Ekuitas di Pasar Reguler Bursa Efek.

\section{Leasing Syariah}

Pembiayaan syariah atau yang lebih dikenal dengan leasing syariah, sebagai tuntutan sistem industri keuangan non-bank yang inovatif, inklusif, dan kontributif dalam pembangunan ekonomi yang berkelanjutan.Sebagai awal bagi operasional leasing syariah, DSN-MUI sudah mengeluarkan aturan terkait leasing syariah, yaitu: Fatwa No. 9/DSN-MUI/IV/2000 tentang Pembiayaan Ijarah, Fatwa No. 27/DSN-MUI/III/2002 tentang Al-Ijarah Al-Muntahiyah Bi Al-Tamlik,

${ }^{12}$ Fatwa DSN-MUI, http://mui.or.id/produk-mui/fatwa-mui/fatwa-dsn-mui, diakses tanggal 20 Desember 2015. 
selanjutnya Fatwa No. 56/DSN-MUI/V/2007 tentang Ketentuan Review Ujrah Pada Lembaga Keuangan Syariah. Adanya regulasi dari fatwa oleh DSN-MUI,13 maka diterbitkannya aturan dari Bank Indonesia dalam bentuk PBI No. 7/46/PBI/2005 tentang Akad Penghimpunan dan Penyaluran Dana bagi Pihak Bank yang melaksanakan Kegiatan Usaha Berdasarkan Prinsip Syariah, paragraf 3 Pasal 15, 16, 17 penjelasan tentang Ijarah Muntahiyah bi Tamlik. Selanjutnya, dari lembaga pengawas lain, seperti BAPEPAM-LK mengeluarkan Peraturan Nomor: PER-03/BL/2007 tentang Kegiatan Perusahaan Pembiayaan Berdasarkan Prinsip Syariah. ${ }^{14}$ Selanjutnya, OJK sebagai lembaga independen yang saat ini berwenang mengatur dan mengawasi jalannya industri keuangan syariah non-bank pada khususnya juga mengeluarkan POJK Nomor 31/POJK.05/2014 tentang Penyelenggaraan Usaha Pembiayaan Syariah. ${ }^{15}$

\section{Sektor IKNB Lainnya}

Selain asuransi syariah dan pembiayaan syariah (leasing syariah), yang termasuk ruang lingkup industri keuangan syariah non-bank tidak lain adalah pegadaian syariah, modal ventura syariah, Multi Level Marketing Syariah (MLM Syariah), dan masih banyak industri lainnya yang bergerak di keuangan syariah. Maka dari itu, lembaga terkait seperti BI, OJK, Kementrian Keuangan dan pihak lainnya, semakin dituntut untuk membuat regulasi terkait dengan munculnya industri keuangan syariah yang semakin inovatif.

Di pegadaian syariah misalnya, belum ada regulasi khusus yang mengatur mengenai pegadaian syariah. Sebelumnya sudah ada aturan terkait tentang pegadaian konvensional dalam PP No. 103 Tahun 2000 tentang Perusahaan Umum Pegadaian. Namun regulasi tersebut sebatas hanya mengatur pegadaian konvensional. Maka dari itu, muncul fatwa DSN-MUI No.25/DSN-MUI/III/2002 untuk mengatur produk yang menggunakan akad gadai ( $r a h n)$ untuk diterapkan pada industri keuangan syariah seperti pegadaian syariah.

${ }^{13}$ Fatwa DSN-MUI, http://mui.or.id/produk-mui/fatwa-mui/fatwa-dsn-mui, diakses tanggal 20 Desember 2015.

${ }_{14}^{14}$ Peraturan OJK, http://www.ojk.go.id/id/regulasi/otoritas-jasa-keuangan/peraturan-ojk/Default.aspx, diakses tanggal 20 Desember 2015.

${ }^{15} \mathrm{Ibid}$. 
Selanjutnya, pada sektor industri keuangan syariah lainnya seperti kegiatan usaha perdagangan dengan sistem penjualan langsung atau lebih dikenal dengan Multi Level Marketing (MLM) semakin menjamur. Bisnis MLM di Indonesia tidak hanya berada dalam kawasan konvensional saja, namun juga dari kalangan penggiat bisnis yang mengambil peluang di bidang aktifitas bisnis syariah. Munculnya MLM Syariah sejalan dengan kemajuan industri keuangan syariah yang ada di Indonesia. Awal peletakan dasar hukum tentang MLM di Indonesia dimulai dari adanya aturan yang dikeluarkan oleh Menteri Perdagangan dalam bentuk Peraturan Menteri Perdagangan RI Nomor 32/M-DAG/PER/8/2008 tentang Penyelenggaraan Kegiatan Usaha Perdagangan dengan Sistem Penjualan Langsung;Peraturan Menteri Perdagangan RI Nomor 47/M-DAG/PER/9/2009 tentang Perubahan Atas Permendag Nomor 32/M-DAG/PER/8/2008 tentang Penyelenggaraan Kegiatan Usaha Perdagangan dengan Sistem Penjualan Langsung; Peraturan Menteri Perdagangan RI Nomor 55/M-DAG/PER/10/2009 tentang Pendelegasian Wewenang Penerbitan Surat Izin Usaha Penjualan Langsung kepada Kepala Badan Koordinasi Penanaman Modal dalam Rangka Pelaksanaan Pelayanan Terpadu Satu Pintu di Bidang Penanaman Modal; Peraturan Menteri Perdagangan RI Nomor 13/M-Dag/PER/3/2006 tentang Ketentuan dan Tata Cara Penerbitan Surat Izin Usaha Penjualan Langsung; Peraturan Menteri Perdagangan RI Nomor 36/MDAG/PER/9/2007 tentang Penerbitan Surat Izin Usaha Perdagangan; Keputusan Menteri Perindustrian dan Perdagangan RI Nomor 73/MPP/Kep/3/2000 tentang Ketentuan Kegiatan Usaha Penjualan Berjenjang;16 dan untuk memperkuat regulasi terkait keberadaan MLM Syariah, maka dikeluarkannya Fatwa Dewan Syariah Nasional-Majelis Ulama Indonesia (DSN-MUI) Nomor 75/DSN/MUI/VII/2009 tentang Penjualan Langsung Berjenjang Syariah (PLBS). ${ }^{17}$

Modal ventura merupakan bagian sub sistem dari suatu sistem industri pembiayaan, di samping sewa guna usaha (leasing), anjak piutang (factoring), usaha kartu kredit (credit card), pembiayaan konsumen (consumer financing), dan pembiayaan proyek (project finance). Di antara sub sistem lembaga industri ini

16R. Serfianto dkk., Buku Pintar Investasi dan Gadai Emas, Gramedia Pustaka Utama, Jakarta, 2013, hlm. 89.

${ }^{17}$ Fatwa DSN-MUI, http://mui.or.id/produk-mui/fatwa-mui/fatwa-dsn-mui, diakses tanggal 20 Desember 2015. 
merupakan bagian dari sistem industri keuangan bukan bank, yang dibawah pengawasan OJK yang merupakan industri keuangan bukan bank selain pegadaian, pasar modal, dana pensiun dan asuransi. ${ }^{18}$

Produk keuangan syariah yang semakin inovatif ditunjukkan dalam aturan baru mengenai penyertaan modal seperti permodalan dalam negeri, dalam penerapannya berbentuk modal ventura syariah. Meskipun masih dalam tahap dalam pengembangan industri keuangan syariah, akan tetapi hal tersebut menunjukkan bahwa semamakin inovatifnya produk keuangan syariah di Indonesia. Regulasi terkait modal ventura berdasarkan peraturan Keputusan Menteri Keuangan Nomor 1251/KMK.13 Tanggal 20 Desember 1988 tentang Ketentuan dan Tata Cara Pelaksanaan Lembaga Pembiayaan dan Keputusan Menteri Keuangan Nomor 469/KMK.17/1995 tanggal 3 Oktober 1995 tentang Pendirian dan Pemberian Modal Ventura. ${ }^{19}$ Untuk mendorong perkembangan perusahaan modal ventura, di akhir tahun 2015 Otoritas Jasa Keuangan (OJK) mengeluarkan 4 peraturan baru. Peraturan tersebut terdiri dari: POJK Nomor 34/POJK.05/2015 tentang Perizinan Usaha dan Kelembagaan Perusahaan Modal Ventura; POJK Nomor 35/POJK.05/2015 tentang Penyelenggaraan Usaha Perusahaan Modal Ventura; POJK Nomor 36/POJK.05/2015 tentang Tata Kelola Perusahaan Yang Baik Bagi Perusahaan Modal Ventura; POJK Nomor 37/POJK.05 tentang Pemeriksaan Langsung Perusahaan Modal Ventura. ${ }^{20}$

\section{Kedudukan dan Peran Dewan Syariah Nasional dan Dewan Pengawas Syariah sebagai Instrumen Pengawasan Kepatuhan Syariah (Sharia Compliance)}

Di Indonesia, tingkat pengawasan pertama dinamai dengan Dewan Pengawas Syariah (DPS) dan tingkat pengawasan berikutnya di level nasional dinamai dengan Dewan Syariah Nasional (DSN). ${ }^{21}$ DSN merupakan bagian dari Majelis Ulama Indonesia (MUI), yang bukan badan pemerintah namun memiliki

18Sunaryo, Hukum Lembaga Pembiayaan, Sinar Grafika, Jakarta, 2009, hlm. 14.

${ }^{19}$ Abdul Rasyid, Perusabaan Modal Ventura Syariah, http://business-law.binus.ac.id/2016/01/30/ perusahaan-modal-ventura/, diakses tanggal 20 Januari 2016.

${ }^{20}$ Peraturan OJK, http://www.ojk.go.id/id/regulasi/otoritas-jasa-keuangan/peraturan-ojk/Default.aspx, diakses tanggal 20 Januari 2015. 2003, hlm. 39.

${ }^{21}$ Didin Hafidhuddin dan Hendri Tanjung, Manajemen Syariah dalam Praktik, Gema Insani Press, Jakarta, 
otoritas dalam mengeluarkan fatwa terkait dengan masalah-masalah perbankan syariah. Lahirnya UU No. 21 Tahun 2008 tentang Perbankan Syariah menjadi dasar pembentukan Komite Perbankan Syariah yang memformulasikan fatwa DSN ke dalam Peraturan Bank Indonesia (PBI). ${ }^{22}$

Seperti diketahui bahwa anggota DSN terdiri dari beberapa ulama, praktisi, maupun pakar ekonomi syariah yang sebelumnya ditunjuk dan diangkat oleh MUI dengan masa bakti kepengurusan selama lima (5) tahun. DSN memiliki tanggung jawab dalam memastikan atau mengawal kepatuhan syariah, baik dalam produk maupun operasional dari industri keuangan syariah itu sendiri. Untuk mendukung para anggota dewan syariah dalam menjalankan tugasnya, DSN menyiapkan aturan yang diperlukan, terkait dengan kualifikasi keanggotaan, tugas dan kewajiban, pengakuan fatwa yang diterbitkan, serta independensi mereka dari berbagai intervensi dari berbagai pihak. ${ }^{23}$

Tugas DSN adalah mengawasi produk-produk lembaga keuangan syariah agar sesuai dangan ketentuan-ketentuan yang ada di dalam syariah. Maka dari itu, DSN membuat aturan dalam bentuk guidelines dengan mengkaji, menggali, dan merumuskan nilai-nilai dan prinsip-prinsip syariah yang mana dalam bentuk fatwa untuk dijadikan pedoman dalam kegiatan transaksi dan analisis produk dan jasa di lembaga keuangan syariah. Secara rinci, berikut tugas dan wewenang daripada DSN, yaitu: ${ }^{24}$ 1. memberikan atau mencabut rekomendasi nama-nama yang akan duduk sebagai anggota DPS pada suatu lembaga keuangan syariah; 2. mengeluarkan fatwa atas jenis-jenis kegiatan keuangan; 3. mengeluarkan fatwa atas produk dan jasa keuangan syariah; 4 . mengawasi penerapan fatwa yang telah diterapkan.

Untuk menjalankan tugas dan wewenangnya, DSN merekomendasikan seorang atau cendekiawan muslim untuk menjadi Dewan Pengawas Syariah (DPS) yang bertugas untuk mengawasi jalannya operasional industri keuangan syariah agar sesuai dengan ketentuan-ketentuan di dalam syariah yang didasarkan pada

22 Pasal 26 ayat (4) dan (5) UU No 21 Tahun 2008 tentang Perbankan Syariah.

${ }^{23}$ Surat Edaran Gubernur Bank Indonesia No. 8/19/DPBS tentang Pedoman Pengawasan Syariah dan TataCara Pelaporan Hasil Pengawasan bagi Dewan Pengawas Syariah.

${ }^{24}$ Rizal Yahya dkk., Akuntansi Perbankan Syariah Teori dan Praktik Kontemporer, Salemba Empat, Jakarta, 2009, hlm. 27. 
guidelines. 25 Terkait dengan tugas dan wewenang DPS, sebagaimana dalam surat keputusan MUI No. Kep-98/MUI/2001 tentang susunan DPS-MUI, adalah sebagai berikut: ${ }^{26} 1$. melakukan pengawasan secara periodik pada lembaga keuangan syariah yang berada di bawah pengawasannya; 2 . berkewajiban mengajukan usul-usul pengembangan produk lembaga keuangan syariah yang diawasinya kepada pimpian lembaga yang bersangkutan kepada DSN; 3. melaporkan perkembangan produk dan operasional lembaga keuangan syariah yang diawasinya kepada DSN sekurangkurangnya 2 kali dalam 1 tahun anggaran; 4. merumuskan permasalahanpermasalahan yang memerlukan penambagan yang memerlukan pembahasan DSN.

Model pengawasan oleh DPS terhadap industri keuangan syariah, di mana DPS sebagai supervisory body. DPS dari yang mengawasi bank syariah bertanggung jawab untuk melaporkan isu-isu kepatuhan syariah ke DSN. Berdasarkan laporan tersebut, DSN meneruskan ke BI atupun OJK untuk dilakukan investigasi terkait dengan isu yang dilaporkan. Dalam hal pelaporan kepada DSN, bahwa DPS harus membuat pernyataan secara berkala dalam menjalankan tugasnya di lembaga keuangan syariah. Pernyataan tersebut dimuat dalam bentuk laporan tahunan (annual report) di bank yang bersangkutan. Selain itu, DPS adalah pihak sebagai penyaring pertama atas suatu produk yang baru dikeluarkan oleh lembaga keuangan syariah sebelum produk tersebut diteliti kembali dan difatwakan oleh pihak DSN. ${ }^{27}$

Terkait dengan proses pengawalan kepatuhan syariah, proses pengawalan kepatuhan syariah oleh DPS mengikuti aturan yang telah ditetapkan oleh Accounting And Auditing Organization for Islamic Financial Institutions (AAOIFI) dan Islamic Financial Services Board (IFSB), yang menegaskan adanya pengawasan sebelum bisnis dijalankan (ex ante) dan setelah bisnis dijalankan (ex post).28 Selanjutnya, dalam Government Standart for Islamic Financial Institution (GSIFI) No.

${ }^{25}$ Andri Soemitra, Bank dan Lembaga Keuangan Syariah, Kencana, Jakarta, 2009, hlm. 42.

${ }^{26}$ Khaerul Umam, Manajemen Perbankan Syariah, Pustaka Setia, Bandung, 2013, hlm. 382.

27 Agus Triyanta, "Implementasi Kepatuhan Syariah Dalam Perbankan Islam (Syariah): Studi Perbandingan Antara Malaysia dan Indonesia", Jurnal Hukum Ius Quia Iustum, Edisi Khusus Vol. 16 No. 4, Oktober, 2009, hlm. 223.

${ }^{28}$ Accounting And Auditing Organization for Islamic Financial Institutions (AAOIFI) No. 2, on Sharia Review, 2002, hlm. 16. Lihat juga Islamic Financial Services Board (IFSB), Guiding Principles On Corporate Governance For Institutions Offering Only Islamic Financial Services (Excluding Islamic Insurance (Takaful) Institutions And Islamic Mutual Funds), Guiding Principles 11, 2006. 
2 dalam paragraf 7 menyebutkan, bahwa tiga (3) prosedur dalam pelaksanaan sharia review yaitu planning review procedures, executing review procedure and review of working papers, and documenting conclusions and report. Dalam standar planning review procedures bertujuan untuk memperoleh pemahaman yang menyeluruh atas operasional lembaga keuangan syariah yang meliputi produk, skala operasi, lokasi, kantor cabang perusahaan, anak perusahaan, serta divisi-divisinya yang bertujuan untuk memperoleh daftar dari semua fatwa, aturan, dan petunjuk yang dikeluarkan oleh DPS. Selanjutnya dalam standar executing review procedure and review of working papers and documenting conclusions and report bertujuan untuk menemukan hasil dari temuan audit dengan melakukan serangkaian pengujian atas transaksi dan dokumen, serta mendokumentasikan semua prosedur atas audit yang telah dilakukan selama pemeriksaan..$^{29}$

DPS memiliki peranan penting dalam meminimalisir dan menghindari adanya kemungkinan penyimpangan terhadap kepatuhan syariah (sharia compliance). Melalui pengawasan tersebut, maka DPS diharapkan dapat membantu untuk mengevaluasi dan mendeteksi sejauhmana pelaksanaan atau implementasi kepatuhan syariah ditetapkan dan sejauhmana penyimpangan yang terjadi dalam mengevaluasi kepatuhan syariah oleh industri keuangan syariah atas prinsipprinsip syariah. Keberadaan dari DPS diharapkan dapat memfokuskan dirinya dalam mengembangkan dan mengawal industri keuangan syariah atas produk yang dikeluarkan maupun operasional yang bersangkutan yang diawasinya agar selalu berjalan sesuai dengan prinsip-prinsip yang ada di dalam koridor syariah.

DSN dapat memberikan sanksi berupa teguran kepada industri keuangan syariah jika industri yang bersangkutan menyimpang dari guidelines yang telah ditetapkan dalam fatwa DSN. ${ }^{30} \mathrm{Hal}$ ini dilakukan ketika DSN memperoleh laporan dari tiap-tiap DPS pada industri keuangan syariah yang melakukan penyimpangan terhadap kepatuhan syariah yang telah ditetapkan. Ketidakpatuhan semacam itu, berarti sebuah pelanggaran atau pencederaan terhadap kerangka regulasi yang ada, di mana hukuman akan dikenakan. Hukuman yang dimaksud dapat berupa

${ }^{29}$ Adrian Sutedi, Pasar Modal Syariah Sarana Investasi Kenangan Berdasarkan Perinsip Syariah, Sinar Grafika, Jakarta, 2011, hlm. 251.

${ }^{30}$ Muhammad Syafi'i Antonio, Bank Syariah dari Teori ke Praktik, Gema Insani, Jakarta, 2009, hlm. 236. 
berbagai macam hukuman, mulai dari yang bersifat administratif semacam surat peringatan. Kemudian, apabila pihak industri keuangan syariah tidak mengindahkan teguran yang diberikan oleh DSN, maka pihak DSN dapat mengusulkan kepada otoritas yang berwenang seperti OJK, serta instansi terkait lainnya, untuk memberikan sanksi dan tindakan tegas seperti pencabutan izin usaha/lisensi agar industri keuangan syariah tersebut tidak mengembangkan lebih jauh atas tindakan-tindakan yang melanggar ketentuan-ketentuan yang ada di dalam syariah. Hukuman yang bersifat pidana dapat juga dijatuhkan bagi orangorang yang bertanggung jawab mengelola bisnis terkait dalam institusi yang dijalankan selama dapat dibuktikan telah melakukan kesalahan berupa pelanggaran prinsip-prinsip yang ada di dalam syariah.

Selanjutnya terkait dengan kualifikasi yang ditetapkan mengenai perekrutan keanggotaan dewan syariah bahwa ada beberapa kriteria yang ditentukan. Kualifikasi utamanya adalah bahwa calon anggota dewan syariah harus menguasai masalah terkait fikih muamalat dan pengetahuan atau praktik di bidang transaksi keuangan. Kualifikasi ini sejalan dengan apa yang disarankan oleh para ahli dalam hukum Islam. Meski demikian, nampak bahwa akan ada diskualifikasi dari anggota jika mereka tidak menunaikan tugas dengan baik (misconduct).

Dalam hal perangkapan jabatan, bahwa anggota pengawas syariah boleh merangkap dengan jabatan yang sama di bank lain, ditambah dengan dua institusi keuangan syariah non-bank, serta juga dapat sebagai anggota DSN, bahkan menurut Bank Indonesia, sekarang perangkapan dapat lebih banyak dari tahuntahun sebelumnya.

\section{Dewan Pengawas Syariah sebagai Otoritas Pengawas Kepatuhan Syariah (Sharia Compliance)}

Dewan Pengawas Syariah sebagai pemegang otoritas pengawasan terhadap kepatuhan syariah (sharia compliance), memiliki tanggung jawab yang diatur melalui ketentuan hukum yang tegas. Jika dilihat dalam peraturan perundangundangan serta praktik yang dilakukan oleh industri keuangan syariah, DPS ditempatkan pada posisi yang sangat strategis. Kedudukan DPS sangat 
menentukan terciptanya kepatuhan syariah (sharia compliance) yang merupakan unsur utama dalam keberadaan dan kelangsungan usaha bagiindustri keuangan syariah. Dari hasil penelitian oleh Khotibul Umam, bahwa diperlukan sikap profesional yang harus dimiliki oleh seorang DPS dalam melaksanakan tugas serta wewenangnya sebagai pengawas industri keuangan syariah, yang sedikitnya ada lima (5) prinsip minimal yang harus dirumuskan dalam penyusunan standar etik profesional di antara lain: ${ }^{31}$ pertama, bertanggung jawab. DPS harus melaksanakan tugas dan wewenangnya dengan sebaik-baiknya, sebagai bentuk tanggung jawabnya menjadi pengawas dalam kepatuhan syariah dalam menjaga masyarakat terhadap profesionalitas DPS. Kedua, Integritas Tinggi. Dalam melaksanakan tugas, DPS harus jujur dan setia terhadap nilai dan norma yang berlaku, baik dari segi hukum positif maupun normatif (syariah) agar dapat mempertahankan kepercayaan masyarakat. Ketiga, Independensi. Seorang DPS harus bersikap objektif, bebas dari intervensi dari siapapun, serta bebas dari segala pertantangan kepentingan dalam melaksanakan tugas dan wewenang sebagai pengawas dalam industri keuangan syariah. Keempat, kecermatan. DPS selalu memperhatikan standar teknis dan standar etika dalam melaksanakan tugasnya dan membuka diri untuk terus belajar dalam meningkatkan kualitas kompetensi diri sebagai DPS yang memeiliki sifat profesionalitas. Kelima, bersikap Profesional. DPS harus bersungguh-sungguh dalam melaksanakan tugas dan wewenangnya yang didukung dengan pengetahuan, keterampilan dan wawasan yang sangat luas sehingga dapat menyelesaikan setiap permasalahan seperti konflik yang ada dengan efektif dan efisien.

\section{Penutup}

Dewan Pengawas Syariah (DPS) sebagai pemegang otoritas pengawasan terhadap kepatuhan syariah (sharia compliance), memiliki tanggungjawab yang diatur melalui ketentuan hukum yang tegas. Jika dilihat dalam peraturan perundang-undangan serta praktik yang dilakukan oleh industri keuangan

${ }^{31}$ Khotibul Umam, "Urgensi Standarisasi Dewan Pengawas Syariah dalam Meningkatkan Kualitas Audit Kepatuhan Syariah”, Panggung Hukum, Vol. 1, No. 2, Juni 2015. 
syariah, DPS ditempatkan pada posisi yang sangat strategis. Kedudukan DPS sangat menentukan terciptanya kepatuhan syariah (sharia compliance) yang merupakan unsur utama dalam keberadaan dan kelangsungan usaha bagi industri keuangan syariah. Serta masih adanya permasalahn terkait DPS terkait dengan perangkapan jabatan, yang masih menyisakan banyak permasalahan. Maka dari itu, perlu sikap profesional yang tinggi, selain ilmu pengetahuan, keahlian, serta wawasan yang luas dalam bidang syariah.

\section{Daftar Pustaka}

Didin Hafidhuddin and Hendri Tanjung, Manajemen Syariah dalam Praktik, Gema Insani Press, Jakarta, 2003.

Accounting And Auditing Organization for Islamic Financial Institutions (AAOIFI) No. 2, on Sharia Review, 2002.

Antonio, Muhammad Syafi'i, Bank Syariah dari Teori ke Praktik, Gema Insani, Jakarta, 2009.

Fatwa DSN-MUI, http://mui.or.id/produk-mui/fatwa-mui/fatwa-dsn-mui, diakses tanggal 20 Desember 2015.

Islamic Financial Services Board (IFSB), Guiding Principles On Corporate Governance For Institutions Offering Only Islamic Financial Services (Excluding Islamic Insurance (Takaful) Institutions And Islamic Mutual Funds), Guiding Principles 11, 2006.

Ilhami, Haniah, "Pertanggungjawaban Dewan Pengawas Syariah Sebagai Otoritas Pengawas Kepatuhan Syariah Bagi Bank Syariah", Mimbar Hukum, Vol. 21, No. 3, Oktober 2009.

Noman, Abdullah M., "Imperatives of Financial Innovations For Islamic Banks", International Journal of Islamic Financial Services, Vol. 3, 2003.

Peraturan Bank Indonesia, http://www.bi.go.id/id/peraturan/perbankan/ Default.aspx, diakses tanggal 20 Desember 2015.

Peraturan OJK, http://www.ojk.go.id/id/regulasi/otoritas-jasa-keuangan/ peraturan-ojk/Default.aspx, diakses tanggal 20 Desember 2015.

R. Serfianto dkk., Buku Pintar Investasi dan Gadai Emas, Gramedia Pustaka Utama, Jakarta, 2013.

Rizal Yahya dkk., Akuntansi Perbankan Syariah Teori dan Praktik Kontemporer, Salemba Empat, Jakarta, 2009.

Rasyid, Abdul, Perusahaan Modal Ventura Syariah, http://businesslaw.binus.ac.id/2016/01/30/perusahaan-modal-ventura/ 
Setiawan, Aziz Budi, "Perbankan Syariah: Challenges Dan Opportunity Untuk Pengembangan Di Indonesia", Jurnal Kordinat, Vol. VIII: 1, April 2006.

Soemitra, Andri, Bank dan Lembaga Keuangan Syariah, Kencana, Jakarta, 2009.

Sunaryo, Hukum Lembaga Pembiayaan, Sinar Grafika, Jakarta, 2009.

Sutedi, Adrian, Pasar Modal Syariah Sarana Investasi Keuangan Berdasarkan Perinsip Syariah, Sinargrafika, Jakarta, 2011.

Triyanta," Agus "Implementasi Kepatuhan Syariah Dalam Perbankan Islam (Syariah): Studi Perbandingan Antara Malaysia dan Indonesia", Jurnal Hukum Ius Quia Iustum, Edisi Khusus Vol. 16 No. 4, Oktober, 2009.

Umam, Khaerul, Manajemen Perbankan Syariah, Pustaka Setia, Bandung, 2013.

Umam, Khotibul, “Urgensi Standarisasi Dewan Pengawas Syariah dalam Meningkatkan Kualitas Audit Kepatuhan Syariah", Panggung Hukum, Vol. 1, No. 2, Juni 2015.

UU No. 21 Tahun 2008 tentang Perbankan Syariah.

UU No. 23 Tahun 1999 tentang Bank Indonesia.

UU No. 10 Tahun 1998 tentang Perubahan Atas UU No. 7 Tahun 1992 tentang Perbankan. 